\title{
NILAI-NILAI KEARIFAN LOKAL PADA UNGKAPAN TRADISIONAL UPACARA PERNIKAHAN MASYARAKAT DESA REMBAN KABUPATEN MURATARA PROVINSI SUMATERA SELATAN
}

\author{
Mega Ardiati ${ }^{1}$, Sainil Amral ${ }^{2}$, Ade Rahima ${ }^{3}$ \\ Program Studi Pendidikan Bahasa dan Sastra Indonesia \\ Fakultas Keguruan dan Ilmu Pendidikan Universitas Batanghari \\ Jambi \\ Megaardiati2197@gmail.com \\ amralsainil@gmail.com \\ ade_rahima@yahoo.com
}

\begin{abstract}
The purpose of this research is to describe (1) the values of local genius on the traditional custom expressions in the stage pre-marriage of the society in Remban Muratara District Sumsel Province; (2) The values of local genius on the traditional custom expressions in the stage of the wedding day of the society in Remban Muratara Regency Sumsel Province; (3) The values of local genius on the traditional custom expressions in the stage of post-marriage in Remban District Muratara Sumsel province. This type of research is qualitative descriptive. The data in this research is the traditional custom expressions of marriage ceremony. The is data analyzed by using content analysis technique. Based on the analysis of the data, it shows that : (1) Local genius values in the aspect of courtesy norms on traditional custom expressions in the stage of pre-marriage in Remban Muratara Sumsel is politeness norm which can bes seen from the expression man di kami segalo jadi, kalu di kawan bukan saot, (2) The values of local genius in the aspect of politeness norms on traditional custom expressions of the wedding day in Remban District Muratara Sumsel province is modesty norm which can be seen in the expression tepak ko betando kami menepati janji, and (3) the values of local genius in the aspect of politeness values of the traditional custom expression in the stage of post-marriage in Remban Muratara Regency of Sumsel Province is modesty which can be seen in the expression kami menabor beras kunyit, selamatan hidup sampai mati.
\end{abstract}

Keywords: Local Genius Values, Politeness Norm, Traditional Custom Expressions in Wedding Ceremony

\footnotetext{
${ }^{1}$ Mahasiswa Program Studi Pendidikan Bahasa dan Sastra Indonesia, Fakultas Keguruan dan Ilmu Pendidikan, Universitas Batanghari Jambi

${ }^{2}$ Dosen Program Studi Pendidikan Bahasa dan Sastra Indonesia, Fakultas Keguruan dan Ilmu Pendidikan, Universitas Batanghari Jambi

${ }^{3}$ Dosen Program Studi Pendidikan Bahasa dan Sastra Indonesia, Fakultas Keguruan dan Ilmu Pendidikan, Universitas Batanghari Jambi
}

Nilai-nilai Kearifan Lokal pada Ungkapan Tradisional Upacara Pernikahan Masyarakat Desa Remban Kabupaten Muratara Provinsi Sumatera Selatan 


\section{PENDAHULUAN}

Pada abad ini, manusia Indonesia cendrungan mengikuti gaya hidup baru yang trendy dan menempatkan nilai-nilai baru dalam keberhasilan. Sampai pada batas tertentu nilai-nilai tersebut telah merusak nilai-nilai tradisional yang sebelumnya dipegang teguh dan diyakini kebenarannya dalam masyarakat serta merupakan suatu bentuk kearifan lokal masyarakatnya Rahima, 2017:1). Pendapat ini menunjukkan bahwa gaya hidup masyarakat saat ini yang tidak dapat memperhatikan nilai-nilai kearifan lokal

Karya sastra merupakan suatu wujud gagasan seseorang melalui pandangan terhadap lingkungan sosial di sekelilingnya. Karya sastra sebuah karya yang kreatif yang diciptakan dengan ideide yang cemerlang. Rokhmansyah (2014: 8), mengatakan bahwa karya sastra dapat dijadikan tuntunan ke depannya dalam menjalani hidup yang menumbuhkembangkan nilai-nilai dalam kehidupan manusia. Berdasarkan pendapat di atas bahwa karya sastra sangat penting bagi kehidupan manusia, selain itu karya sastra banyak menghasilkan nilai-nilai kearifan yang ada dilingkungan sosial.

Salah satu karya sastra yang mengandung nilai-nilai kearifan lokal ialah sastra lisan. Pada dasarnya sastra lisan merupakan bagian dari foklor yaitu segala sesuatu yang mencakup dalam kehidupan kebudayaan rakyat serta adat istiadat, kepercayaan, dongeng, dan ungkapan, (Webster (dalam Rafiek, 2010: 54)). Sastra lisan menarik untuk dikaji karena dalam sastra lisan terdapat nilainilai kearifan lokal terutama nilai-nilai yang mengacu kepada aspek norma kesopanan adat-istiadat dalam upacara pernikahan. Penelitian ini difokuskan pada ungkapan tradisional yang mengandung nilai-nilai kearifan lokal pada aspek norma kesopanan adat istiadat upacara pernikahan. Hal ini bertujuan untuk mempertahankan suatu adat pada masyarakat Desa Remban Kabupaten Musi Rawas Utara Provinsi Sumatera Selatan.

Penelitian ini penting untuk dilakukan, dilatarbelakangi oleh beberapa hal, yaitu: 1) banyak masyarakat yang belum mengetahui atau tidak mementingkan nilai-nilai kearifan lokal dalam aspek norma kesopanan adat istiadat upacara pernikahan pada Desa Remban Kabupaten Musi Rawas Utara Provinsi Sumatera Selatan contohnya, kebanyakan masyarakat sekarang yang menikah tanpa sepengetahuan orang tuanya, dan banyak remaja yang sudah melakukan hubungan terlarang sehingga berdampak pada kehamilan tanpa menikah terlebih dahulu; 2) serta melestarikan budaya karena adat-istiadat mulai tergerus oleh budaya luar; 3) dan pendokumentasian ungkapan adat istiadat.

Fokus permasalahan dalam penelitian ini hanya mengacu pada nilainilai kearifan lokal dalam aspek norma kesopanan adat istiadat pada ungkapan tradisional upacara pernikahan, pada tahap sebelum pernikahan, tahap hari pernikahan dan tahap setelah pernikahan masyarakat Desa Remban Kabupaten Musi Rawas Utara Provinsi Sumatera Selatan.

Adapun pertanyaan yang harus dijawab dalam penelitian ini meliputi 3 pertanyaan, sebagai berikut.

1. Bagaimanakah nilai-nilai kearifan lokal aspek norma kesopanan adat istiadat ungkapan tradisional pada tahap sebelum pernikahan masyarakat di Desa Remban Kabupaten Musi Rawas Utara Provinsi Sumatera Selatan?

2. Bagaimanakah nilai-nilai kearifan lokal aspek norma kesopanan adat

Nilai-nilai Kearifan Lokal pada Ungkapan Tradisional Upacara Pernikahan Masyarakat Desa Remban Kabupaten Muratara Provinsi Sumatera Selatan 
istiadat ungkapan tradisional pada tahap hari pernikahan masyarakat di Desa Remban Kabupaten Musi Rawas Utara Provinsi Sumatera Selatan?

3. Bagaimanakah nilai-nilai kearifan lokal aspek norma kesopanan adat istiadat ungkapan tradisional pada tahap setelah pernikahan masyarakat di Desa Remban Kabupaten Musi Rawas Utara Provinsi Sumatera Selatan?

Adapun penelitian ini bertujuan untuk mendeskripsikan nilai-nilai kearifan lokal pada aspek norma kesopanan adat istiadat ungkapan tradisional pada tahap sebelum pernikahan, hari pernikahan, dan setelah pernikahan masyarakat di Desa Remban Kabupaten Musi Rawas Utara Provinsi Sumatera Selatan.

\section{Kajian Pustaka}

Endraswara

mengatakan bahwa sastra lisan adalah karya penyebarannya disampaikan dari mulut ke mulut secara turun temurun. Menurut Webster (dalam Rafiek, (2010:54)) sastra lisan merupakan bagian dari foklor yaitu dari segala sesuatu yang mencakup dalam kehidupan kebudayaan rakyat serta adat istiadat, kepercayaan, dongeng, dan ungkapan.

Fajarini (2014: 123) mengatakan bahwa kearifan lokal adalah pandangan hidup dan ilmu pengetahuan serta berbagai strategi kehidupan yang berwujud aktivitas yang dilakukan oleh masyarakat lokal dalam menjawab berbagai masalah dengan pemenuhan mereka.

Selanjutnya menurut Haryanto (2014:212) bentuk-bentuk kearifan lokal adalah kerukunan beragaman dalam wujud praktik sosial yang dilandasi suatu kearifan dari budaya. Bentuk-bentuk kearifan lokal dalam masyarakat dapat berupa budaya (nilai, norma, etika, kepercayaan, adat istiadat, hukum adat, dan aturan-aturan khusus). Nilai-nilai luhur terkait kearifan lokal meliputi cinta kepada Tuhan, alam semesta beserta isinya, tanggung jawab, disiplin, dan mandiri, jujur, hormat dan santun, kasih sayang dan peduli, percaya diri, kreatif, kerja keras, pantang menyerah, keadilan, kepemimpinan, baik, rendah hati, toleransi, cinta damai dan persatuan.

$$
\text { Santosa (2015: }
$$

mengungkapkan ciri-ciri kearifan lokal, yaitu: 1) mampu bertahan terhadap budaya luar; 2) memiliki kemampuan mengakomodasi unsur-unsur budaya; 3) mempunyai kemampuan mengendalikan;4) mampu memberi arah pada perkembangan budaya.

Sartini (dalam Basyari, (2014:48), mengatakan fungsi kerifal local antara lain: 1) kearifan lokal berfungsi untuk konverensi dan pele starian sumber daya alam; 2) kearifan lokal berfungsi untuk mengembangkan sumber daya manusia; 3) berfungsi sebagai pengembangan kebudayaan dan ilmu pengetahuan; 4) berfungsi sebagai petuah,kepercayaan, sastra dan pantangan; 5) sebagai sarana membentuk membangun integrasi komunal; 6) sebagai landasan etika dan moral, yang mewujudkan dalam upacara adat; dan 7) bermakna politik.

Menurut, Wibawa (2012:3) norma kesopanan, yaitu peraturan atau kaidah yang bersumber dari pergaulan hidup antar manusia. Selanjutnya, Widjaja (dalam Ziyadi, (2017: 281)) mengatakan bahwa norma kesopanan adalah aturan hidup bermasyarakat tentang tingkah laku yang baik dan tidak baik, patut dan tidak patut dilakukan, yang berlaku dalam suatu lingkungan masyarakat atau komunitas tertentu. Norma ini biasanya bersumber dari adat istiadat, budaya, atau nilai-nilai masyarakat.

\section{Nilai-nilai Kearifan Lokal pada Ungkapan Tradisional Upacara Pernikahan Masyarakat Desa} Remban Kabupaten Muratara Provinsi Sumatera Selatan 
Adapun dalam kehidupan masyarakat, norma kesopanan memiliki beberapa fungsi, sebagai berikut.

a) Menghalangi setiap individu bersikap di luar fase kesopanan pada biasanya.

b) Belajar menghormati diri sendiri.

c) Norma kesopanan tersebut mengait budaya ketimuran yang melandasi kehidupan, dan pelanggaran tidak berakibat hukum hanya berakibat pada hukuman sosial saja dan norma tersebut mudah beralih bergantung pada sikap masyarakat itu sendiri.

Adapun ciri-ciri dari norma kesopanan dalam kehidupan masyarakat, yaitu sebagai berikut:

a) berasal dari pergaulan;

b) berbentuk kawasan ataupun kewilayahan;

c) hukumannya berupa cacian dari masyarakat.

Menurut Husin (2004:85) “Adat merupakan suatu peraturan yang dilaksanakan (diamalkan) secara turuntemurun dalam sebuah masyarakat, hingga menjadi hukum dan peraturan yang harus dipatuhi”. Sementara istiadat adalah peraturan atau cara melakukan sesuatu yang diterima sebagai adat.

Menurut Effendy (2004: 61) ada empat tingkatan adat yang dijelaskan sebagai berikut:

1. Adat yang sebenar adat menurut Effendy (2004: 61) "Adat yang sebenar adat adalah inti adat yang berdasar kepada ajaran aggama Islam. Adat inilah yang tidak boleh dianjakalih, diubah, dan ditukar. Adat berdasar kepada pengertian manusia terhadap eksistensi dan sifat alam yang kasat mata ini.

2. Adat yang diadatkan adalah adat itu bekerja pada suatu landasan tertentu, menurut mufakat dari penduduk daerah tersebut. Kemudian pelaksanaannya diserahkan oleh rakyat kepada yang dipercayai mereka. Sebagai pemangku adat adalah seorang raja atau penghulu. Pelaksaan adat ini wujudnya adalah untuk kebahagiaan penduduk, baik lahir ataupun batin, dunia dan akhirat, pada saat itu dan saat yang akan datang. Adat yang diadatkan ini maknanya mengarah kepada sistemsistem sosial yang dibentuk secara bersama, dalam asas musyawarah untuk mencapai kesepakatan. Adat yang diadatkan juga berkaitan erat dengan sistem politik dan tata pemerintahan yang dibentuk berdasarkan nilai-nilai keagamaan, kebenaran, keadilan, kesejahteraan, dan polarisasi yang tepat sesuai dengan perkembangan dimensi ruang dan waktu yang dilalui masyarakat melayu.

3. Adat yang teradat adalah kebiasaankebiasaan yang secara berangsurangsur atau cepat menjadi adat. Adat yang teradat ini merupakan konsep masyarakat Melayu terhadap kesinambungan dan perubahan, yang merupakan respons terhadap dimensi ruang dan waktu yang dijalani manusia di dunia ini. Manusia, alam, dan seisinya, pastilah berubah menurut waktu dan zamannya. Namun demikian, perubahan pastilah tetap disertai dengan kesinambungan yang berasal dari era-era dan keadaan sebelumnya.

4. Adat istiadat

Adat-istiadat merupakan kumpulan dari berbagai kebiasaan yang telah banyak diartikan tertuju kepada upacara khusus seperti adat, perkawinan, penobatan raja, dan pemakaman raja. Adat istiadat ini adalah ekspresi dari kebudayaan melayu. Upacara di dalam kebudayaan melayu juga mencerminkan pola pikir atau gagasan masyarakat melayu.

\section{Nilai-nilai Kearifan Lokal pada Ungkapan Tradisional Upacara Pernikahan Masyarakat Desa} Remban Kabupaten Muratara Provinsi Sumatera Selatan 
Selanjutnya, Athaillah (dalam Anton, (2015:5)) mengatakan bahwa "Ungkapan tradisional merupakan ungkapan yang dikenal oleh masyarakat pendukungnya. Ungkapan tersebut telah berkembang secara turun-temurun dengan makna dan simbol yang terkandung didalamnya yg bersifat tetap.

\section{Langkah-langkah Upacara Pernikahan pada Masyarakat Desa Remban Kabupaten Musi Rawas Utara Provinsi Sumatera Selatan}

Upacara pernikahan merupakan serangkaian kegiatan tradisional turuntemurun yang mempunyai maksud dan tujuan agar sebuah perkawinan selamat sejahtera serta mendatangkan kebahagiaan di kemudian hari, (Kamal, 2014: 1). Pernikahan merupakan suatu hal yang sakral dan mulia bagi kehidupan setiap manusia agar hidupnya bahagia lahir dan batin, serta damai dan mewujudkan rasa kasih antara keduannya (Satriana, 2015: 15).

Upacara pernikahan pada masyarakat Desa Remban Kabupaten Musi Rawas Utara Provinsi Sumatera Selatan mempunyai tiga langkah yaitu tahap sebelum pernihakan, tahap hari pernikahan dan tahap setelah petnikahan.

\section{Tahap Sebelum Pernikahan}

Adapun tahapan dan ungkapan yang ada pada tahap sebelum pernikahan ini yaitu mencakup 6 tahap yaitu:

\section{Berasanan}

Berasan merupakan suatu bentuk permusyawarahan, dalam berasanan ini banyak hal yang dibicarakan menyangkut kelanjutan acara tersebut. Pada tahap berasanan ini hanya melibatkan pihak keluarga laki-laki dan perempuan saja. Biasanya, jika sudah pada tahapan ini semua permasalahan sudah mendapatkan jalan keluarnya dan sudah disepakati bersama. Hanya tinggal membicarakan yang bersifat sangat penting, pembicaraan dalam pertemuan lanjutan yaitu di sebut mutus kato. Tahap berasanan ini biasannya menggunakan ungkapan tradisional yang sudah lama dipakai oleh masyarakat Desa Remban Kabupaten Musi Rawas Utara Provinsi Sumatera Selatan.

\section{Mutus Kato}

Mutus kato atau mutusin rasanan dalam bahasa daerah Palembang berarti membuat perembukan atau mengambil kata sepakat tentang kapan hari dan tanggal pernikahan akan dilangsungkan dan dengan cara bagaimana dan apa persyaratannya. Pada tahapan ini biasanya juga menggunakan ungkapan tradisional yang digunakan oleh masyarakat Desa Remban Kabupaten Musi Rawas Utara Provinsi Sumatera Selatan.

\section{Antaran Pintakan}

Antaran pintakan suatu tahapan sesudah mutus kato isi dari antaran pintakan ini yaitu apa saja yang dibicarakan pada tahap mutus kato dan merupakan bahwa pihak laki-laki menepati janji yang telah disepakati. Pada tahapan ini biasanya digunakan ungkapan tradisional masyarakat Desa Remban Kabupaten Musi Rawas Utara Provinsi Sumatera Selatan. Tahapan ini dipakai untuk penyerahan persyaratan yang diminta untuk berlangsungnya acara sebelum hari pernikahan yaitu isi nya berupa uang yang digunakan dalam proses pernikahan.

\section{Memasak atau Ngocek Bawang}

Tahapan ini termasuk dalam suatu persiapan menjelang hari pernikahan yang tidak mungkin dilakukan sendiri tetapi membutuhkan bantuan dan tenaga banyak orang, terutama bantuan dari pihak keluarga dan tetangga ataupun orang yang menggenal pihak kelarga tersebut, kemudian sebagai rasa suka cita bersama sebagai silahturahmi dengan 
makan-makan bersama. Pada tahapan ini biasanya digunakan ungkapan tradisional masyarakat Desa Remban Kabupaten Musi Rawas Utara Provinsi Sumatera Selatan.

\section{Nyerao}

Nyerao suatu tahap yang dilakukan pihak keluarga untuk memintak tolong berupa tenaga kepada masyarakat yang ditetapkan dan ditugaskan untuk berlangsungnnya acara pernikahan tersebut. Pada tahapan ini biasanya digunakan ungkapan tradisional masyarakat Desa Remban Kabupaten Musi Rawas Utara Provinsi Sumatera Selatan.

\section{Betangas}

Betangas merupakan suatu tahapan membersihkan tubuh dengan air hangat yang disertai dengan wewangian yang dilakukan oleh pihak pengantin. Pada tahapan ini biasanya digunakan ungkapan tradisional masyarakat Desa Remban Kabupaten Musi Rawas Utara Provinsi Sumatera Selatan. Tahapan ini merupakan tahapan terakhir dalam tahap proses sebelum pernikahan.

\section{Tahap Hari Pernikahan}

Adapun pafa tahap hari pernikahan, terdirinatas dua tahapan yaitu: akad nikah dan penyerahan mahar penyemban.

\section{Akad Nikah}

Tahapan ini merupakan tahapan yang sangat penting. Tahap akad nikah ini merupakan suatu kegiatan yang sakral yang wajib dilakukan oleh setiap orang yang dianjurkan Allah swt. Pada tahapan ini biasanya digunakan ungkapan tradisional masyarakat Desa Remban Kabupaten Musi Rawas Utara Provinsi Sumatera Selatan.

\section{Penyerahan Mahar dan Penyemban}

Tahapan ini merupakan tahapan penepatan janji yang telah disepakati bersama yang berisi mahar dan penyemban yaitu berupa peralatan rumah tangga untuk kedua mempelai dalam melanjutkan kehidupannya selesai menikah. Pada tahapan ini biasanya digunakan ungkapan tradisional masyarakat Desa Remban Kabupaten Musi Rawas Utara Provinsi Sumatera Selatan. Tahapan ini merupakan tahapan terakhir dari tahap pernikahan kemudian dilanjutkan pada tahap setelah pernikahan.

\section{Tahap Setelah Pernikahan}

Tahap setelah pernikahan ini merupakan tahapan terakhir yang terdiri atas 4 kegiatan, yaitu: berarak-arak, tabur beras kunyit, beratib, dan samenoh.

\section{Berarak-arak}

Tahap berarak-arak ini tahap yang dilkaukan selesai akad nikah, berarak-arak dilakukan untuk memberitahu kepada masyarakat di lingkungannya bahwa kedua mempelai sudah sah atau resmi menjadi suami istri. Pada tahapan ini biasanya digunakan ungkapan tradisional masyarakat Desa Remban Kabupaten Musi Rawas Utara Provinsi Sumatera Selatan, kemudian dilanjutkan pada tahap tabur besar kunyit.

\section{Tabur Beras Kunyit}

Tabur beras kunyit merupakan tahapan yang dilakukan pihak keluarga perempuan dan laki-laki sebagai ungkapan terimakasih dan sebagai selamatan hidup. Pada tahapan ini biasanya digunakan ungkapan tradisional masyarakat Desa Remban Kabupaten Musi Rawas Utara Provinsi Sumatera Selatan.

\section{Beratib}

Tahapan beratib ini ucapan syukur kepada Allah swt serta rasa terimakasih yang dilakukan antara keluarga kedua pihak pengantin. Tahap ini dilakukan di rumah pengatin perempuan dan diikuti oleh seluruh 
keluarga serta masyarakat yang di undang dalam tahap tersebut. Pada tahapan ini biasanya digunakan ungkapan tradisional masyarakat Desa Remban Kabupaten Musi Rawas Utara Provinsi Sumatera Selatan.

\section{Samenoh}

Samenoh suatu tahapan yang dilakukan kedua mempelai dengan berkunjung ke rumah keluarga kedua mempelai dengan membawa makanan dan perwakilan dari keluarga masingmasing. Pada tahapan ini biasanya digunakan ungkapan tradisional masyarakat Desa Remban Kabupaten Musi Rawas Utara Provinsi Sumatera Selatan. Tahapan ini dilakukan untuk menyerahkan kedua mempelai kepada keluarga yang baru dan mengajak untuk sama-sama menjaga kedua mempelai. Tahapan ini merupakan tahapan berakhirnya proses tahap tata cara pernikahan yang ada pada masyarakat Desa Remban Kabupaten Musi Rawas Utara Provinsi Sumatera Selatan.

\section{METODE PENELITIAN}

Dalam penelitian sastra terdapat beberapa sudut pandang atau pendekatan serta metode dalam menganalisis sebuah karya. Perbedaan pendekatan dan metode inilah yang kemudian memunculkan adanya berbagai jenis penelitian sastra (Rahima,2017:6)

Terkait hal tersebut, maka jenis penelitian ini termasuk penelitian deskriptif kualitatif. penelitian deskriptif kualitatif adalah penelitian dengan pengumpulan data pada suatu latar alamiah dan menggambarkan objek secara alamiah pula (Moeleong, 2012:5). Oleh karena itu dalam penelitian ini, peneliti menggambarkan secara lamiah dan apa adanya nilai-nilai kearifan lokal dalam ungkapan tradisional upacara pernikahan masyarakat desa Remban Kabupaten Muratara Provinsi Sumatera
Selatan. Selain itu, menurut Endraswara (2013: 8) metode penelitian sastra bersifat deskriptif kualitatif adalah cara yang dipilih oleh peneliti dengan mempertimbangkan bentuk, isi, dan sifat sastra sebagai subjek kajian.

Menurut Siswantoro (2010: 70) data primer adalah data utama yaitu data yang diseleksi atau yang diperoleh langsung dari sumbernya tanpa perantara. Data primer dalam penelitian ini ialah teks ungkapan tradisional dalam upacara pernikahan melalui mewawancara ketua adat Desa Remban Kabupaten Musi Rawas Utara Provinsi Sumatera Selatan. Selanjutnya Siswantoro (2010: 71) mengemukakan bahwa "Data sekunder adalah data yang diperoleh secara tidak langsung atau melalui perantara, tetapi tetap bersandar kepada kategori atau parameter yang menjadi rujukan". Data sekunder dalam penelitian ini merupakan teori yang berhubungan dengan ungkapan tradisional dalam upacara pernikahan masyarakat Desa Remban Kabupaten Musi Rawas Utara Provinsi Sumatera Selatan.

Data penelitian diperoleh dari Desa Remban Kabupaten Musi Rawas Utara Provinsi Sumatera Selatan, berupa ungkapan tradisional upacara pernikahan adat Desa Remban Kabupaten Musi Rawas Utara Provinsi Sumatera Selatan.

$$
\text { Sugiyono (2011: 308) }
$$

menyatakan "Teknik pengumpulan data merupakan langkah yang paling utama dalam penelitian, karena tujuan utama dari penelitian adalah mendapatkan data. Tanpa mengetahui teknik pengumpulan data, maka peneliti tidak akan mendapatkan data yang memenuhi standar data yang ditetapkan”. Teknik pegumpulan data dalam penelitian ini adalah teknik observas, wawancara, dan rekam.

$\begin{array}{ccc}\text { Teknik observasi } & \text { digunakan } \\ \text { dalam penelitian ini. } & \text { Observasi }\end{array}$ 
merupakan suatu pengamatan yang digunakan dalam rangka mengumpulkan data dalam suatu penelitian.

Djojosuroto dan Sumaryati (2010: 47) mendefinisikan "Wawancara adalah teknik pengumpulan data yang digunakan peneliti untuk mendapatkan keteranganketerangan lisan melalui bercakap-cakap dan berhadapan muka dengan orang yang dapat memberikan keterangan pada si peneliti. Wawancara ini dapat dipakai untuk melengkapi data yang diperoleh oleh melalui observasi.

Teknik rekam digunakan penulis untuk mempermudah dalam mendokumentasikan atau mengarsipkan data penelitian. Teknik rekam merupakan teknik yang dilakukan secara langsung terhadap objek penelitian dengan tujuan untuk memperoleh data dan sebagai bukti nyata dari pemerolehan data tersebut. Menurut, Muhammad (2011: 210) "Teknik rekam adalah teknik yang harus digunakan dalam penelitian dengan cara merekam menggunakan alat rekam sebagai arsip penelitian". Teknik rekam di dalam penelitian ini digunakan sebagai salah satu teknik memperoleh data mengenai nilai-nilai kearifan lokal dalam ungkapan tradisional upacara pernikahan pada masyarakat Desa Remban Kabupaten Musi Rawas Utara Provinsi Sumatera Selatan. Alat yang dipakai untuk merekam yang digunakan oleh peneliti dalam memperoleh data dari informan yaitu menggunakan Headphone.

Analisis data dalam penelitian ini dilakukan berdasarkan teori, Usman (dalam Siregar, (2014: 63)) dan dimodivikasi sesuai kebutuhan peneliti, sebagai berikut.

1. Reduksi data

Data dari lapangan berupa sumber lisan maupun tulisan yang kemudian ditulis direduksi, dirangkum, difokuskan kepada hal yang berhubungan dengan objek yang akan diteliti yakni nilai-nilai kearifan lokal dalam aspek norma kesopanan adat istiadat pada ungkapan tradisional upacara pernikahan masyarakat Desa Remban Kabupaten Musi Rawas Utara Provinsi Sumatera Selatan. Fungsi dari reduksi data ini adalah mengarahkan, menajamkan, menggolongkan, mengorganisir, serta membuang yang tidak perlu sehingga kesimpulannya bisa ditarik dan diferivikasi.

2. Penyajian data

Penyajian data adalah sekumpulan informasi yang memberikan kemungkinan adanya penarikan kesimpulan dan pengambilan data ke dalam sebuah matrik, grafik, dan bagan yang diinginkan. Penyajian data dalam penelitian ini dilakukan dengan memilih data yang lebih relevan dengan konteks penelitian.

3. Pengambilan kesimpulan dan verifikasi

Mengambil keputusan dan verifikasi yaitu berusaha mencari penjelasan alur sebab akibat melalui penambahan data baru yang berkaitan dengan objek penelitian tentang niali-nilai kearifan lokal dalam aspek norma kesopanan adat istiadat pada ungkapan tradisional upacara pernikahan masyarakat Desa Remban Kabupaten Musi Rawas Utara Provinsi Sumatera Selatan.

\section{HASIL DAN PEMBAHASAN}

Berdasarkan analisis data nilainilai kearifan lokal dalam aspek norma kesopanan adat istiadat pada ungkapan tradisional upacara pernikahan masyarakat Desa Remban Kabupaten Musi Rawas Utara Provinsi Sumatera Selatan, ditemukan 40 ungkapan. Ungkapan tersebut diperoleh dari beberapa tahapan dalam rangkaiaan upacara pernikahan. Pada tahap sebelum pernikahan diperoleh 16 bait ungkapan; 
tahap hari pernikahan diperoleh 15 bait ungkapan, dan tahap setelah pernikahan diperoleh 9 bait ungkapan.

Nilai-nilai Kearifan Lokal Ungkapan Tradisional Upacara Pernikahan pada Tahap Sebelum Pernikahan

Ungkapan nilai-nilai kearifan lokal dalam aspek norma kesopanan adat istiadat pada tahap sebelum pernikahan meliputi berasanan, mutus kato, antaran pintakan, memasak atau ngocek bawang, nyerao dan betangas. Adapun ungkapan tersebut dijelaskan sebagai berikut.

Kutipan ungkapan 1

"Samarinda negeri asal daerah (Samarinda negeri asal daerah)

Kota Palembang tempat tujuan (kota Palembang tempat tujuan)

Hajat hati nalak saudara (maksud hati mencari saudara)

Nak menjalen kekeluargaan (ingin menjalin kekeluargaan)", (Az/tb).

Pada ungkapan tradisional tersebut terdapat kutipan yang termasuk dalam aspek norma kesopanan adat istiadat pada tahap sebelum pernikahan masyarakat Desa Remban Kabupaten Musi Rawas Utara Provinsi Sumatera Selatan. Kutipan tersebut adalah Hajat hati nalak saudara, nak menjalen kekeluargaan, yang disampaikan oleh pihak laki-laki.

Ungkapan Hajat hati nalak saudara, nak menjalen kekeluargaan, menjelaskan bahwa setiap melakukan pernikahan pihak laki laki harus datang dengan maksud, tujuan dan niat hati untuk menjalin suatu kekeluargaan yang baik sehingga dapat diterima dengan baik. Apabila masyarakat tidak mengikuti norma kesopanan adat istiadat biasanya ada suatu tindakan yang di luar keinginan keluarga misalnya, ada penolakan dari pihak keluarga perempuan kemudian menikah secara diam-diam serta perbuatan tersebut akan berdampak pada anggota keluarga masing-masing. Hal tersebut bisa dinamakan pernikahan yang tidak disetujui oleh pihak keluarga. Hal ini sesuai dengan pendapat Widjaja (dalam Ziyadi, 2017: 281) yang mengatakan bahwa "Norma kesopanan adalah aturan hidup bermasyarakat tentang tingkah laku yang baik dan tidak baik, patut dan tidak patut dilakukan, yang berlaku dalam suatu lingkungan masyarakat atau komunitas tertentu".

Nilai-nilai Kearifan lokal Ungkapan Tradisional Upacara Pernikahan pada Tahap Hari Pernikahan

Ungkapan nilai-nilai kearifan lokal dalam aspek norma kesopanan adat istiadat pada tahap hari pernikahan meliputi: akad nikah dan penyerahan mahar atau penyemban. Adapun ungkapan tersebut dijelaskan sebagai berikut.

Kutipan ungkapan 2

"Sayang cak ciap burung cak ciap (sayang tiruan bunyi anak ayam burung bunyi tiruan anak ayam)

Nak terbang ke arah Mekah (mau terbang ke arah Mekah)

Man kawan lah siap kami lah siap (kalau kalian sudah siap kami sudah siap)

Payohlah kito akad nikah (marilah kita akad nikah)", (Az/takd).

Ungkapan tersebut termasuk salah satu aspek norma kesopanan adat istiadat. Hal tersebut dapat diketahui dari ungkapan yang disampaikan pihak lakilaiki yaitu man kawan lah siap kami lah siap, payolah kito akad nikah. Ungkapan tersebut menjelaskan bahwa setiap melakukan pernikahan harus ada persetujuan dari pihak perempuan, pada 
tahap akad nikah pihak laki-laki harus menanyakan kepada pihak perempuan, apakah akad nikah siap dilaksanakan? Hal tersebut merupakan tingkah laku yang patut dilakukan, dan pertanyaan itu harus di pikir dengan baik oleh pihak perempuan. Hal ini sesuai dengan pendapat Widjaja (dalam Ziyadi, 2017: 281) yang mengatakan bahwa "Norma kesopanan adalah aturan hidup bermasyarakat tentang tingkah laku yang baik dan tidak baik, patut dan tidak patut dilakukan, yang berlaku dalam suatu lingkungan masyarakat atau komunitas tertentu".

\section{Nilai-nilai Kearifan Lokal Ungkapan Tradisional Upacara Pernikahan pada Tahap Setelah Pernikahan}

Nilai-nilai kearifan lokal pada aspek norma kesopanan adat istiadat dalam ungkapan tradisional tahap setelah pernikahan, meliputi: berarak-arak, tabur beras kunyit, beratib dan samenoh. Adapun ungkapan tersebut dijelaskan sebagai berikut.

Kutipan ungkapan 3

"Pisang Kayak tumbuh di Mekah (pisang Kayak tumbuh di Mekah)

Nak di baok ke kota Jambi (mau di bawak ke kota Jambi)

Kami ngarak sudah menikah (kami iring-iringan bersama sudah menikah)

Nak meresmi kalu sudah jadi (mau meresmi kalau sudah jadi)", (Az/tbrk).

Ungkapan tersebut, termasuk dalam norma kesopanan pada tahap setelah pernikahan dalam adat istiadat. Hal tersebut dapat diketahui dari ungkapan yang disampaikan oleh pihak keluarga yaitu kami ngarak sudah menikah, nak meresmi kalu sudah jadi. Ungkapan tersebut menjelaskan bahwa setiap melakukan pernikahan tahap berarak- arak merupakan tahap yang bersumber dari adat istiadat, pada masyarakat tersebut karena berarak-arak dilakukan dengan berjalan kaki mengelilingi dusun tempat tinggal mempelai diikuti oleh anggota keluarga serta masyarakat setempat, tahap tersebut dilakukan untuk memberi tahu kepada masyarakat bahwa kedua mempelai sudah sah atau resmi jadi suami istri. Apabila hal tersebut tidak dilakukan, maka pihak keluarga diangap tidak mengikuti aturan adat sehingga di pandang tidak baik. Hal ini sesuai dengan pendapat Zuriah (dalam Kholifah, 2017: 2) yang mengatakan bahwa "Norma kesopanan adalah sikap dan perilaku yang tertib sesuai dengan adat istiadat atau norma-norma yang berlaku di dalam masyarakat".

\section{SIMPULAN}

Berdasarkan hasil penelitian dan pembahasan, dapat disimpulkan bahwa nilai-nilai kearifan lokal dalam aspek norma kesopanan adat istiadat pada ungkapan tradisional upacara pernikahan masyarakat Desa Remban Kabupaten Musi Rawas Utara Provinsi Sumatera Selatan terdiri dari 3 tahap yaitu tahap sebelum pernikahan, tahap hari pernikahan dan tahap setelah pernikahan. Jumlah ungkapan aspek norma kesopanan adat istiadat pada tiga tahap upacara pernikahan masyarakat Desa Remban Kabupaten Musi Rawas Utara Provinsi Sumatera Selatan. sebanyak 40 ungkapan.

Jumlah ungkapan nilai-nilai kearifan lokal dalam aspek norma kesopanan adat istiadat pada ungkapan tradisional upacara pernikahan masyarakat Desa Remban Kabupaten Musi Rawas Utara Provinsi Sumatera Selatan, pada tahap sebelum pernikahan sebanyak 16 ungkapan. Dari ke-16 ungkapan tersebut dapat disimpulkan bahwa terdapat norma kesopanan adat istiadat yang telah di

Nilai-nilai Kearifan Lokal pada Ungkapan Tradisional Upacara Pernikahan Masyarakat Desa Remban Kabupaten Muratara Provinsi Sumatera Selatan 
lakukan oleh kedua pihak, dengan cara bermusyawarah bersama dalam mengambil keputusan, sesuai dengan ungkapan, man di kami segalo jadi, kalu di kawan bukan saot.

Jumlah ungkapan nilai-nilai kearifan lokal dalam aspek norma kesopanan adat istiadat pada ungkapan tradisional upacara pernikahan masyarakat Desa Remban Kabupaten Musi Rawas Utara Provinsi Sumatera Selatan pada tahap hari pernikahan sebanyak 15 ungkapan. Dari ke-15 ungkapan tersebut dapat disimpulkan bahwa terdapat norma kesopanan adat istiadat yang telah di lakukan oleh kedua pihak, dengan saling menepati janji yang telah disepkati sebelumnya serta memenuhi persyaratan yang telah disepakati, sesuai dengan ungkapan, tepak ko betando kami menepati janji.

Jumlah ungkapan nilai-nilai kearifan lokal dalam aspek norma kesopanan adat istiadat pada ungkapan tradisional upacara pernikahan masyarakat Desa Remban Kabupaten Musi Rawas Utara Provinsi Sumatera Selatan, pada tahap setelah pernikahan sebanyak 9 ungkapan. Dari ke-9 ungkapan tersebut dapat disimpulkan bahwa terdapat norma kesopanan adat istiadat yang telah di lakukan oleh kedua pihak, dengan mengucapkan doa selamat kepada kedua mempelai agar dapat menjalankan rumah tangga yang harmonis dan mengucapkan rasa syukur karena adat telah di laksanankan, sesuai dengan ingkapan, kami menabor beras kunyit, selamatan hidup sampai mati.

\section{DAFTAR PUSTAKA}

Anton. (2015) Ungkapan Tradisional dalam Upacara Adat Perkawinan Masyarakat Bajo di Pulau Balu Kabupaten Muna Barat. Jurnal
Humanaika. Vol 3. No 15. Desember.

Basyari, Iin Warin. (2014). Nilai-Nilai Kearifan Lokal (Local Wisdom) Tradisi Memitu pada Masyarakat Cirebon. Jurnal. Edunomic. Vol 2. No 1.

Djojosuroto dan Sumaryati. (2010). Prinsip-Prinsip Dasar Penelitian Bahasa dan Sastra. Bandung: Nuansa.

Endraswara, Suwardi. (2013).

Metodologi Penelitian Sastra.

Yogyakarta: CAPS

(Center for Academic Publishing Service).

Fajarini, Ulfah. (2014), Peranan Kearifan Lokal dalam Pendidikan

Karakter. Jurnal Sosio

Didaktika. Vol 1. No 2.

Desember.

Haryanto. (2014). Asessmen Pendidikan. Bandung: PT Remaja Rosdakarya.

Kamal, Fahmi. (2014). Perkawinan Adat Jawa Dalam Kebudayaan Indonesia. Jurnal Beranda. Vol 5. No 2.

Kholifah. (2017). Studi Tentang Sopan Santun pada Peserta Didik. Jurnal. Universitas Muhammadiyah Purwokerto.

Moleong, Lexi J. (2013). Metodologi Pendidikan Kualitatif. Bandung: PT Remaja Rosdakarya Offset.

Muhammad. (2011). Metode Penelitian Bahasa. Yogyakarta: Ar-Ruzz Media.

Rafiek, M. (2010). Teori Sastra Kajian Teori dan Praktik. Bandung: Refika Aditama.

Rokhmansyah. (2014). Studi dan Pengkajian Sastra. Yogyakarta: Pustaka Pelajar.

Santosa. (2016) Hakikat Perkawinan Menurut Undang-Undang Perkawinan Hukum Islam dan 
Hukum Adat. Jurnal YUDISIA. Vol 7. No 2. Desember.

Satriana, Eka. (2015) Makna Ungkapan pada Upacara Perkawinan Adat Bulukumba di Desa Buhung Bundang Kec. Bontotiro Kab. Bulukumba. Vol 3. No 15. Tahun 2015.

Siregar, Anijar Hapni. (2014). Pola Asuh pada Keluarga Migran Asal Sumatera Utara (Studi Kasus Terhadap Keluarga Migran yang Berprofesi Sebagai Supir Angkutan Umum di Bandung) Universitas Pendidikan Indonesia.
Siswantoro. (2010). Metode Penelitian Sastra. Yogyakarta: Pustaka Pelajar.

Sugiyono. (2011). Metode Penelitian Pendidikan. Bandung: Alfabeta.

Wibawa, Angga Cahya. (2012). Penanaman Nilai Moral pada Anak dalam Keluarga Nelayan Dukuh Tanjungsari. Unnes Civic Education Joernal. Vol 1. No 1.

Ziyadi, Ahsan. (2017). Pentingnya Pengenalan Pelajaran Norma Melalui Strategi Pembelajaran Menyenangkan Dengan Humor. Prosiding Seminar Nasional Tahunan Fakultas Ilmu Sosial Universitas Negeri Medan. 